\title{
Prostatic Hemorrhage
}

National Cancer Institute

\section{Source}

National Cancer Institute. Prostatic Hemorrhage. NCI Thesaurus. Code C78572.

Bleeding originating from the prostate gland. 